\title{
Effects of experimental subclinical fasciolosis* on the feeding behaviour of sheep
}

\author{
I. Ferre ${ }^{1 * *}$, J. González-Gallego ${ }^{2}$, F. A. Rojo-Vázquez ${ }^{1}$ \\ and J. P. Barrio ${ }^{2}$ \\ ${ }^{I}$ Department of Animal Pathology (Animal Health), \\ ${ }^{2}$ Department of Physiology, Pharmacology and Toxicology, \\ University of León \\ 24071 León, Spain
}

(Received 13 November 1995; accepted 12 April 1996)

\begin{abstract}
Ten female Churra breed sheep were experimentally infected with 25 Fasciola hepatica metacercariae daily during six days. The animals were offered pelleted lucerne and water ad libitum. Feed and water intake was automatically recorded by computer monitoring of electronic balances. Liver damage caused by flukes was ascertained by measuring the activities of aspartate amino transferase, glutamate dehydrogenase and gamma-glutamyl transferase. Serum bile acids and glucose concentrations were also measured. Maximum plasma enzyme values were found at 10 weeks post infection. Plasma bile acid concentration increased from six to 13 weeks post infection. Glycaemia was decreased from the fourth week post infection until the end of the experiment. Total daily food intake decreased maximally between six and 12 weeks post infection. The number of meals per day and time spent eating and drinking decreased along the experimental infection. The rate of eating and drinking increased progressively. An association between anorexia and liver damage is suggested.
\end{abstract}

KEY WORDS: Fasciola hepatica, sheep, pathology-trematoda, liver enzymes, anorexia, feed pattern, drink pattern, feeding behaviour

* According to the guidelines of the Standarized Nomenclature of Animal Parastic Diseases (SNOAPAD), the term fasciolosis is used throughout this article

** Corresponding present address: Estación Agricola Experimental-CSIC, Apdo. 788, 24080 León, Spain 


\section{INTRODUCTION}

Fasciolosis ${ }^{1}$ by Fasciola hepatica is a common parasitic disease of domestic ruminants worldwide. Fasciolosis in sheep usually appears as a subclinical infection, causing economic losses difficult to quantify (Boray, 1985).

Appetite depression in sheep infected with Fasciola hepatica is well documented (Boray, 1969; Sinclair, 1972; Berry et al., 1976; Hawkins et al., 1978; Sykes et al., 1980a). Reduced daily food intake is a major factor impairing productivity (Dargie, 1987), but the relationship between the infection and the anorectic effects is still unclear. As an example, both the minimum parasite burden required for the reduction of food intake, and the physiological basis for the infected sheep to decrease their food intake, are still unanswered questions (Symons, 1985; Dargie, 1987).

The study of some liver enzymes serum levels is an important tool for the diagnose of this disease, allowing to differentiate the successive phases of the infection by specific changes related to the migration of immature flukes through the liver parenchyma or to the presence of adult worms in the bile ducts (Anderson et al., 1977; Rowlands et al., 1979; Sykes et al., 1980b; Bulgin et al., 1984; Boray, 1985; Ferre et al., 1994).

As far as we know, no studies have yet been conducted that relate the biochemical changes induced by the parasitic infection to the feeding behaviour of the host. The present research was undertaken in order to evaluate the effects of subclinical experimentally-induced fasciolosis on feeding and drinking behaviour of sheep, including total feed and water intake as well as meal patterns and chronological distribution during the day.

\section{MATERIAL AND METHODS}

\section{Animals}

A total of 10 female growing Churra breed sheep aged six months were housed in individual metabolism cages under controlled temperature and light. They were provided a pelleted lucerne diet ( 0.19 crude protein) and water ad libitum, given once early in the morning after removal of the refusals of the previous day. Enough feed was offered to make sure the refusals were never less than $15 \%$.

\section{Experimental design}

A longitudinal study was performed in order to avoid the interindividual variation that in sheep can be notably large, either considering nutrition, 
biochemical or any other parameters. By which each subject was included itself as a control and post infection values were compared to basal data prior to the experimental infection for each particular animal. The experimental period was 170 days, including a 50-day control period before the infection was performed.

\section{Infection procedure}

The animals were kept under the described conditions until their body weight reached $25 \pm 0.5 \mathrm{~kg}$. At this time each animal was orally infected with 150 Fasciola hepatica metacercariae in a gelatin capsule at a dose rate of 25 metacercariae daily for six days. The metacercariae used to infect the animals were produced under standard laboratory conditions in experimentally infected snails (Limnaea truncatula). Metacercariae were kept at $4^{\circ} \mathrm{C}$ in distilled water during five months until administered.

\section{Feeding behaviour}

An automatic setup was used to measure the removal of feed and water from the respective containers. Briefly, electronic balances (Precisa, Zürich, Switzerland) with $12,000 \pm 0.1 \mathrm{~g}$ weighing capacity were connected through serial ports to personal computer where a control program continuously received the weight data; start and finish times and weights of each feeding and drinking activity were detected by monitoring the differences between the incoming data and the preceding ones, being the results added to a daily data file. This system operated on the week prior to the infection and the $2 \mathrm{nd}, 4 \mathrm{th}, 6 \mathrm{th}, 8 \mathrm{th}, 10 \mathrm{th}$ and 13 th weeks post infection. However, total daily feed intake was measured throughout the experimental period. The feeding and drinking behaviour of five animals was recorded during each week. In order to compare feed and water intake patterns, a day was divided in six periods of four hours. A feed or water intake episode of activity was considered as a meal whenever the interval preceding it was larger than $25 \mathrm{~min}$; otherwise it was interpreted as part of the preceding one. This interval was chosen from the examination of the frequency plot of all recorded intervals between intake activities (Amor, 1994).

Serological analysis

Serum samples were obtained from the jugular vein before infection and at 2 , $4,6,8,10,14$ and 16 weeks post infection. Plasma glucose concentration and activities of aspartate amino transferase (AST, E.C. 2.6.1.1.), glutamate dehydrogenase (GLDH, E.C. 1.4.1.3.) and gamma-glutamyl transferase (GGT, E.C. 2.3.2.2.) were analyzed by commercial available kits (Boeringer Mannheim, 
Barcelona, Spain). Bile acid plasma levels were analyzed with Merckotest $^{\mathrm{TM}}$ (Merck, Madrid, Spain).

\section{Parasitological examination}

Faecal samples were taken twice weekly from the rectum of infected animals starting on six weeks post infection onwards. Fluke egg counts were estimated by a standard sedimentation method using McMaster chambers, and the results were expressed in eggs per gram of faeces (Thienpont et al., 1986).

\section{Statistical procedures}

Results are shown as mean \pm standard error of the mean (SEM). Mean differences were analyzed using the Wilcoxon rank test using the statistical package STATISTICA ${ }^{\mathrm{TM}}$ (Statsoft, Tulsa, OK, USA). $\mathrm{P}<0.05$ were considered significant.

\section{RESULTS}

The experimental infection did not cause apparent clinical signs. The presence of Fasciola hepatica infection was confirmed by the detection of the parasite eggs in the faeces of infected animals 10 weeks post infection. The presence of eggs in faeces reached a peak at 13 weeks post infection, when one infected lamb passed 115 eggs per gram of faeces.

At the end of the experiment, an average of 64 flukes (42-80) were collected from the liver of each experimental animal during necropsy. The percentage of implantation was $43 \%(28-53 \%)$, slightly less than previously reported in other studies (Over et al., 1975).

The plasmatic activities of GLDH and AST were significantly increased at two and four weeks post infection, respectively, reaching both enzymes the highest values at 10 weeks post infection $(+650 \%$ and $+153 \%$ over control values, respectively), progressively falling thereafter (Table 1). Maximum plasma GGT value was reached at 10 weeks post infection $(+147 \%$ vs. controls) (Table 1). The plasma level of bile acids was significantly increased from 6 to 13 weeks post infection (Table 1).

Coinciding with the beginning of fluke migration through the liver parenchyma, a progressive reduction of daily feed intake was observed with the highest slope from 6 to 12 weeks post infection, decreasing thereafter and stabilizing at 13 weeks post infection, after mature flukes started egg-laying (Figure 1). A subsequent tendency to increase daily ingestion was observed (Figure 1). 
TABLE 1

Plasma activities of AST, GLDH and GGT and glucose and bile acid concentration during the course of experimental fasciolosis in young female sheep. Means \pm SEM are given

\begin{tabular}{lccclc}
\hline $\begin{array}{l}\text { Weeks post } \\
\text { infection }\end{array}$ & $\begin{array}{c}\text { AST } \\
(\mathrm{U} / \mathrm{l})\end{array}$ & $\begin{array}{c}\text { GLDH } \\
(\mathrm{U} / \mathrm{l})\end{array}$ & $\begin{array}{c}\text { GGT } \\
(\mathrm{U} / \mathrm{l})\end{array}$ & $\begin{array}{l}\text { Glucose } \\
(\mathrm{mmol} / \mathrm{l})\end{array}$ & $\begin{array}{c}\text { Bile acids } \\
(\mu \mathrm{mol} / \mathrm{l})\end{array}$ \\
\hline Before & $92 \pm 4$ & $18 \pm 1$ & $70 \pm 3$ & $5.47 \pm 0.26$ & $31 \pm 4$ \\
2 & $102 \pm 13$ & $28 \pm 2^{*}$ & $63 \pm 3$ & $5.14 \pm 0.1$ & $34 \pm 5$ \\
4 & $147 \pm 10^{*}$ & $91 \pm 9^{*}$ & $71 \pm 3$ & $4.77 \pm 0.09^{*}$ & $40 \pm 15$ \\
6 & $162 \pm 16^{*}$ & $108 \pm 12^{*}$ & $86 \pm 4^{*}$ & $4.74 \pm 0.09^{*}$ & $56 \pm 15^{*}$ \\
8 & $191 \pm 25^{*}$ & $116 \pm 12^{*}$ & $112 \pm 9^{*}$ & $4.78 \pm 0.1^{*}$ & $48 \pm 13^{*}$ \\
10 & $233 \pm 22^{*}$ & $135 \pm 12^{*}$ & $173 \pm 14^{*}$ & $4.85 \pm 0.08^{*}$ & $50 \pm 12^{*}$ \\
14 & $198 \pm 37^{*}$ & $95 \pm 14^{*}$ & $143 \pm 16^{*}$ & $4.80 \pm 0.11^{*}$ & $50 \pm 13^{*}$ \\
16 & $138 \pm 22$ & $58 \pm 10^{*}$ & $88 \pm 12^{*}$ & $4.85 \pm 0.19^{*}$ & $31 \pm 8^{*}$ \\
\hline
\end{tabular}

$\mathrm{P}<0.05$ (significantly different from control value)

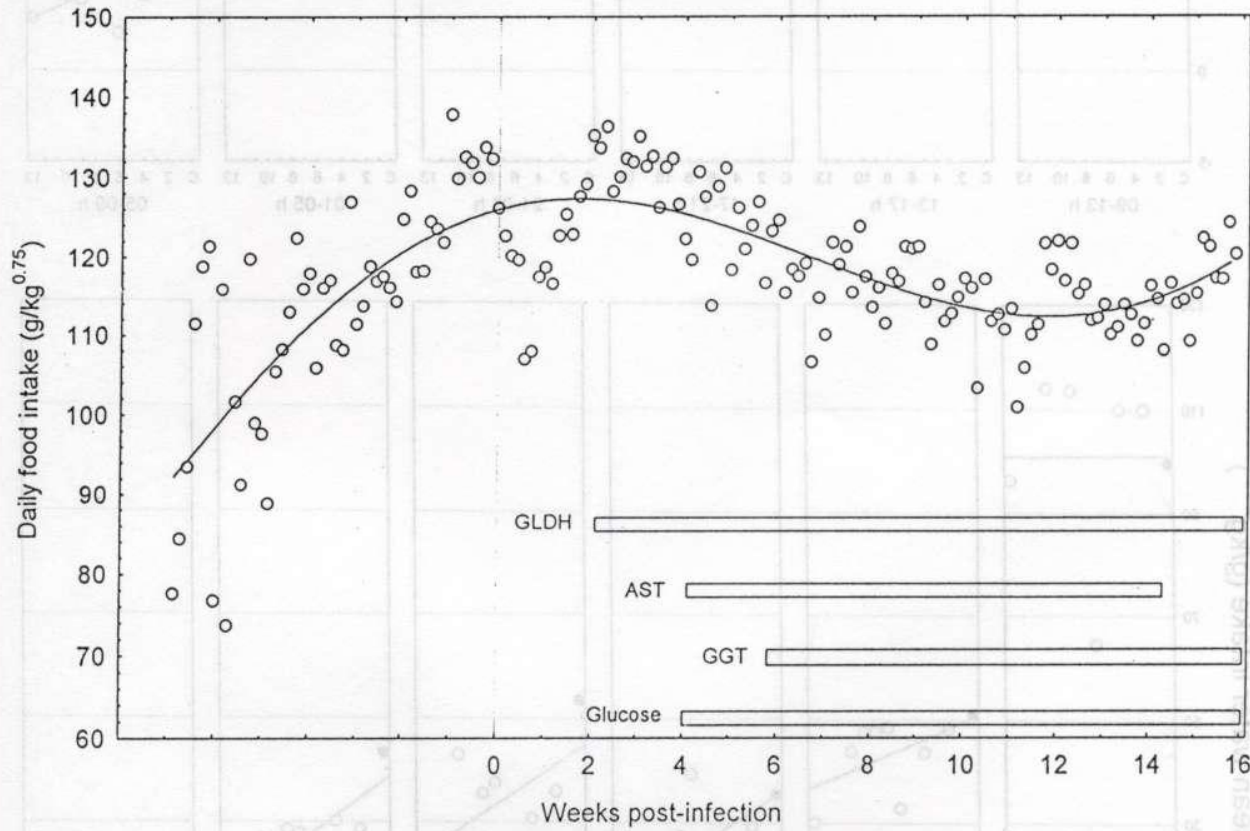

Figure 1. Average daily feed intake during the course of experimental ovine fasciolosis. Periods of significant increase in plasma enzyme activities and significant decrease in glycaemia are indicated by white horizontal bars

Glycaemia was significantly reduced from weeks post infection (Table 1), remaining low to the end of the experiment.

The total daily feed and water intake at different moments of the infection, when the day was divided into six periods of each, showed an apparent trend to eat and drink more during the first period $(09-13 \mathrm{~h})$ (Figure 2). 


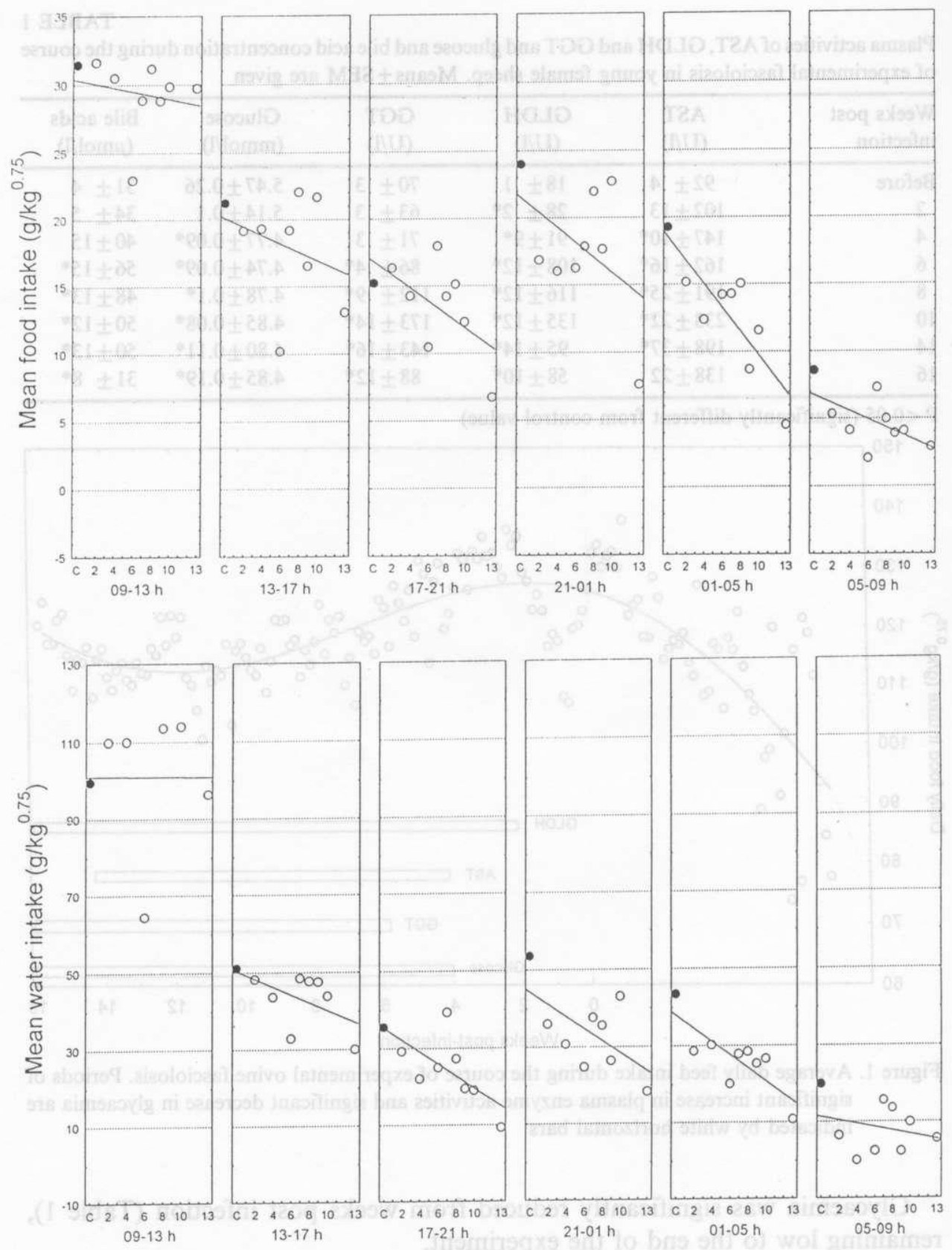

Figure 2. Daily feed (A) and water (B) intake divided into periods of four hours each before (o) and at different weeks (o) of the experimental induced fasciolosis. Periods: 1 (09-13 h); 2 (13-17 h); 3 (17-21 h); 4 (21-24 h, 00-01 h); 5 (01-05 h); and 6 (05-09 h) 
TABLE 2

Total daily feed intake (FI), number of daily meals (NM), total daily time spent eating (TE) and eating rate (ER) at different weeks of the experimental infection. Means SEM are given

\begin{tabular}{lcccc}
\hline Weeks post infection & FI $\left(\mathrm{g} / \mathrm{kg}^{0.75}\right)$ & $\mathrm{NM}$ & $\mathrm{TE}(\mathrm{min})$ & $\mathrm{ER}(\mathrm{g} / \mathrm{min})$ \\
\hline Before & $111.92 \pm 1.6$ & $15.4 \pm 0.33$ & $252.59 \pm 7.64$ & $5.33 \pm 0.25$ \\
2 & $98.74 \pm 2.72$ & $14.3 \pm 0.58$ & $250.24 \pm 6.61$ & $4.52 \pm 0.10$ \\
4 & $117.01 \pm 8.08$ & $16.3 \pm 0.84$ & $256.22 \pm 15.82$ & $5.41 \pm 0.27$ \\
6 & $69.93 \pm 7.42^{*}$ & $13.8 \pm 0.89$ & $201.21 \pm 9.75^{*}$ & $4.37 \pm 0.40$ \\
8 & $109.87 \pm 2.72$ & $15.2 \pm 1.40$ & $221.27 \pm 12.78$ & $6.89 \pm 0.32$ \\
10 & $107.84 \pm 3.81$ & $12.9 \pm 0.30$ & $193.14 \pm 8.89^{*}$ & $8.23 \pm 0.65^{*}$ \\
13 & $74.81 \pm 9.68^{*}$ & $9.1 \pm 1.10^{*}$ & $177.66 \pm 34.58^{*}$ & $7.76 \pm 0.79^{*}$ \\
\hline
\end{tabular}

* $\mathrm{P}<0.05$ (significantly different from control value)

Selected feeding behaviour parameters as total daily feed and water intake, number of meals and drinks taken place in $24 \mathrm{~h}$, total daily time spent eating and drinking, and the eating and drinking rates were recorded (Tables 2 and 3). On the last week of experimental infection significant statistical differences in all parameters studied took place $(\mathrm{P}<0.05)$, while, on the 6 th week post infection, statistical differences were found on total daily feed and water intake, total daily time spent eating and drinking, number of drinks and drinking rate $(\mathrm{P}<0.05)$. Heterogeneity in animal responses can be invoked as responsible for the large s.e. found. In any case, total daily feed intake tended to decrease as the infection progressed, as did the number of meals (and drinks) per day. However, the animals ate (and drank) faster and, as a result, less time was spent eating and drinking. These effects appeared mainly as a tendency when considering feed intake, but were significant at all stages in the case of drinking behaviour.

TABLE 3

Total daily water intake (WI), number of daily drinks (ND), total daily time spent drinking (TD) and drinking rate (DR) in different weeks of the experimental fasciolosis. Means SEM are given

\begin{tabular}{llcrc}
\hline Weeks post infection & WI $\left(\mathrm{g} / \mathrm{kg}^{0.75}\right)$ & ND & TD $(\mathrm{min})$ & DR $(\mathrm{g} / \mathrm{min})$ \\
\hline Before & $262.93 \pm 5.18$ & $14.14 \pm 0.84$ & $50.23 \pm 3.77$ & $106.28 \pm 11.59$ \\
2 & $233.30 \pm 5.11$ & $14.88 \pm 1.22$ & $12.64 \pm 1.43^{*}$ & $257.76 \pm 27.47^{*}$ \\
4 & $277.68 \pm 15.40$ & $14.25 \pm 1.39$ & $8.82 \pm 0.97^{*}$ & $411.62 \pm 24.65^{*}$ \\
6 & $153.61 \pm 7.04^{*}$ & $8.31 \pm 0.99^{*}$ & $7.00 \pm 1.19^{*}$ & $391.88 \pm 55.81^{*}$ \\
8 & $263.20 \pm 5.81$ & $13.63 \pm 0.58$ & $10.15 \pm 0.71^{*}$ & $391.16 \pm 34.39^{*}$ \\
10 & $258.90 \pm 10.80$ & $12.69 \pm 0.96$ & $10.11 \pm 1.37^{*}$ & $462.16 \pm 52.12^{*}$ \\
13 & $175.45 \pm 23.10^{*}$ & $8.25 \pm 1.71^{*}$ & $7.86 \pm 0.87^{*}$ & $343.83 \pm 19.98^{*}$ \\
\hline
\end{tabular}

* $\mathrm{P}<0.05$ (significantly different from control value) 


\section{DISCUSSION}

It is generally admitted that the liver damage caused by the parenchymal migration of the immature flukes is the cause of the increase in plasma GLDH and AST activities, while the increase in GGT activity is associated with the entry of the flukes in the bile ducts (Anderson et al., 1977; Rowlands et al., 1979; Sykes et al., 1980b; Bulgin et al., 1984; Ferre et al., 1994).

Anorexia in the course of ovine fasciolosis has been repeatedly reported (Boray, 1969; Sinclair, 1972; Berry et al., 1976; Hawkins et al., 1978; Sykes et al., 1980a). Inappetence has been associated with the entry of the flukes in the bile ducts, appearing only during the first phases in severe acute infection (Dargie, 1987). The results obtained in this work confirm previous studies (Ferre et al., 1994), showing that the depression of appetite takes place during the period of maximum increase in GLDH and AST plasma activities. Decrease of appetite develops when the deterioration of the hepatic functionality is greater, as confirmed by the increase of plasma bile acids concentration and by the reduction in bile flow and bile acid secretion previously reported (Ferre et al., 1995).

The reduction in glucose plasma levels can be explained on the basis of depressed hepatic glycogen metabolism pathways due to decreased functional hepatic tissue (Ferre et al., 1994), although experimental confirmation is required. Nevertheless, it is clear that the migration of the immature flukes produces a generalized liver dysfunction, as suggested by the concomitant alterations of the energy metabolism in hepatic mitochondria of ewes infected with Fasciola hepatica (Rule et al., 1991).

While reports of decreased total feed intake in ovine fasciolosis are numerous (Dargie, 1987), no data are available on the daily patterns of feed and water intake of the infected animals. The trend to increase feed and water intake during the first four-hour period of the day is common in ewes (Hidari, 1976; Amor, 1994) and it is possibly related to the fact that feed offer stimulates intake (Adams et al., 1983). An increase in the ingestion during the fourth period (20-24 h) has also been observed in healthy animals. This fact has been associated with the smaller satiety effects (by increase in the transit time and decrease of digestibility) of lucerne when offered in pelleted form as compared with other forms of presentation of the feed (Amor, 1994). The results obtained in the ewes before the infection are similar to those reported by Amor (1994) in animals of the same breed. A trend to a decrease in feed and water intake in the infected animals from the second period (13-17 h) onwards can be observed, this decrease being maximum at the 13 weeks post infection.

Though depth of anorexia has been associated with the severity of infection, a relationship between the fluke burden and appetite decrease has not been 
clearly defined (Symons, 1985; Dargie, 1987). In a previous work we have shown a larger decrease in voluntary feed intake in male lambs with as few as 20 flukes (Ferre et al., 1994). In that work each animal ( $35 \mathrm{~kg}$ body weight) was infected orally with 300 Fasciola hepatica metacercariae enclosed in a gelatin capsule, at a dose rate of 10 metacercariae daily for 30 days. In contrast, a more acute infection procedure has now been used, dosing 25 metacercariae daily for six days, given to female lambs ( $25 \mathrm{~kg}$ body weight). The lack of agreement with the results reported in the present paper when considering the parasite burden and feed intake may be associated with the different growth state of the animals used at the time of infection. Experiments are under way to further clarify these questions.

\section{CONCLUSION}

Our results suggest that the decrease in voluntary feed intake in the course of subclinical ovine fasciolosis is probably associated with the liver damage caused by immature flukes, as indicated by plasma liver enzyme levels. When studying feed and water intake patterns, a decrease in total feed and water intake has been seen, as well as a trend for the number of meals and drinks to be diminished. No clues that permit to know the causes of anorexia are available at present, but liver metabolism disturbances induced to the animals by the parasites could have an important role in this behaviour (Galtier et al., 1986).

\section{ACKNOWLEDGEMENTS}

This work has been supported by a grant from the Plan Nacional de Investigación y Desarrollo Ganadero, Spain. Partial results shown in this paper have been presented in the World Sheep \& Wool Congress, 30th July-1st August 1995, Malvern, United Kingdom.

\section{REFERENCES}

Adams G.B., Jones R., Forbes J.M., 1983. Voluntary intake and growth of lambs offred fresh food one or four times per day. Anim. Prod. 36, 508

Amor J., 1994. Estudio de la pauta diaria de ingestión y rumia en ovejas en relación con distintos factores (Relationship between nutritive factors and daily feeding and rumination patterns in sheep). PhD thesis. University of León, Spain 
Anderson P.H., Berrett S., Brush P.J., Hebert N., Parfitt J.W., Patterson, D.S.P., 1977. Biochemical indicators of liver injury in calves with experimental fascioliasis. Vet. Rec. 100, 43-45.

Berry C.I., Dargie J.D., 1976. The role of host nutrition on the pathogenesis of ovine fascioliasis. Vet. Parasitol. 2, 317-332

Boray J.C., 1969. Experimental fascioliasis in Australia. Adv. Parasitol. 7, 96-210

Boray, J.C., 1985. Flukes of domestic animals. In: S.M. Gaafar, W.E. Howard, R.E. Marsh (Editors), Parasites, Pests and Predators. Amsterdam: World Animal Science B2/Elsevier, pp. 179-185

Bulgin M.S., Anderson B.C., 1984. Serum gamma glutamyl transpeptidase activity in cattle with induced fascioliasis. Res. Vet. Sci. 37, 167-171

Dargie J.D., 1987. Trematode infections in sheep and cattle: effects on productivity and metabolism. In: W.H.D. Leaning, J. Guerrero (Editors), The Economic Impact of Parasitism in Cattle. Proceedings of MSD AGVET Symposium, 22 World Veterinary Congress, Montreal, (Canada), pp. 35-43

Ferre I., Barrio J.P., González-Gallego J., Rojo-Vázquez F.A., 1994. Appetite depression in sheep experimentally infected with Fasciola hepatica L. Vet. Parasitol. 55, 71-79

Ferre I., López P., Gonzalo-Orden M., Julian M.D., Rojo-Vázquez F.A., Gonzlez- Gallego J., 1995. The effects of subclinical fasciolosis on hepatic secretory function in sheep. Parasitol. Res. 81, 127-131

Galtier P., Larrieu G., Tufenkji A.E., Franc M., 1986. Incidence of experimental fascioliasis on the activity of drug-metabolizing enzymes in the lamb liver. Drug Metab. Dispos. 14, 137-141

Hawkins C.D., Morris R.S., 1978. Depression of productivity in sheep infected with Fasciola hepatica. Vet. Parasitol. 4, 341-351

Hidari H., 1976. Analysis of diurnal feeding pattern of sheep fed various feeds on free access. Jpn. J. Zootech. Sci. 47, 283-291

Over H.J., Dijkstra J., 1975. Infection rhythm in fascioliasis. In: H.J. Over, J. Armour (Editors), Facts and Reflections II. Lelystad Workshop on Fascioliasis, pp. 9-17

Rowlands D. ap T., Clampitt R.B., 1979. Plasma enzyme levels in ruminants infected with Fasciola hepatica. Vet. Parasitol. 5, 155-175

Rule C.J., Hanisch M.J.E., Behm C.A., Bygrave F.L., 1991. Aberrant energy-linked reactions in mithocondria isolated from livers of sheep infected with the liver fluke Fasciola hepatica. Int. J. Parasitol. 21, 353-355

Sinclair K.B., 1972. The pathogenicity of Fasciola hepatica in pregnant sheep. Brit. Vet. J. 128, 249-259

Sykes A.R., Coop R.L., Rhuston B., 1980a. Chronic subclinical fascioliasis in sheep: effects on food intake, food utilisation and blood constituents. Res. Vet. Sci. 28, 63-70

Sykes A.R., Coop R.L., Robinson M.G., 1980b. Chronic subclinical ovine fascioliasis: plasma glutamate dehydrogenase, gamma glutamyl transpeptidase and aspartate aminotransferase activities and their significance as diagnostic aids. Res. Vet. Sci. 28, 71-75

Symons L.E.A., 1985. Anorexia: occurrence, pathophysiology and possible causes in parasitic infections. Adv. Parasitol. 24, 103-133

Thienpont D., Rochette F., Vanparijs O.F.J., 1986. Diagnosing helminthiasis by coprological examination. Janssen Research Foundation, Beerese, Belgium 


\section{STRESZCZENIE}

\section{Wpływ doświadczalnej subklinicznej fasciolozy na pobranie paszy przez owce}

Dziesięć owiec rasy Churra poddano doświadczalnej codziennej infekcji 25 larwami motylicy wątrobowej przez sześć dni. Zwierzęta żywiono granulowaną lucerną i wodę podawano do woli. Pobranie paszy i wody rejestrowano automatycznie w systemie komputerowego monitoringu wag elektronicznych. Uszkodzenia wątroby spowodowane motylicą wątrobową stwierdzono na podstawie pomiaru aktywności aminotransferazy asparaginianowej, dehydrogenazy glutaminianowej i transferazy gamma-glutamylowej. Oznaczono także stężenie kwasów żólciowych i glukozy w osoczu krwi. Największą aktywność enzymów w osoczu stwierdzono w 10, a stężenie kwasów żółciowych wzrastało od 6 do 13 tygodnia po infekcji. Glikemia zmniejszała się od 4 tygodnia po infekcji aż do końca doświadczenia. Dzienne pobranie paszy zmniejszyło się najbardziej pomiędzy 6 a 12 tygodniem po infekcji. Częstotliwość pobierania paszy i wody w ciągu doby zmniejszała się w miarę postępu infekcji, natomiast tempo jedzenia i picia zwiększało się progresywnie. Otrzymane wyniki doświadczenia sugerują zależność pomiędzy anoreksją a uszkodzeniem wątroby. 